\title{
РЕАБІЛІТАЦІЙНІ ПІДХОДИ ПІСЛЯ ЕНДОПРОТЕЗУВАННЯ КУЛЬШОВИХ СУГЛОБІВ
}

\author{
М. О. Яводчак, Т. Г. Бакалюк, Г. О. Стельмах \\ Тернопільський національний медичний університет \\ імені І. Я. Горбачевського МОЗ України
}

У статті проведено аналіз основних реабілітаційних підходів, які застосовують для пацієнтів після ендопротезування кульшових суглобів. Використання технологій фізичної та реабілітаційної медицини має грунтуватися на результатах якісних рандомізованих контрольованих клінічних дослідженнях, які $€$ основою для розробки клінічних рекомендацій.

\section{REHABILITATION APPROACHES AFTER HIP JOINT ENDOPROSTHETICS}

\author{
M. A. Yavodchak, T. H. Bakaliuk, H. O. Stelmakh \\ I. Horbachevsky Ternopil National Medical University
}

\begin{abstract}
The article analyzes the main rehabilitation approaches used in patients after hip joint endoprosthetics. The use of physical and rehabilitation medicine technologies should be based on the results of qualitative randomized controlled clinical trials, which serve as a basis for the development of clinical guidelines.
\end{abstract}

Вступ. В останні десятиліття обсяги надання високотехнологічної медичної допомоги в галузі ортопедії та травматології істотно зросли, в тому числі ендопротезування кульшового суглоба (ЕКС). У зв'язку 3 цим, збільшується число пацієнтів, які потребують медичної реабілітації. Для якісного вирішення завдань реабілітації необхідне впровадження в практику технологій фізичної та реабілітаційної медицини (ФРМ), ефективність яких доведено в ході якісних наукових досліджень.

На сьогодні визнано, що післяопераційна реабілітація $\epsilon$ ключем до оптимізації результатів проведеного EKC.

Незалежно від типу протеза, його конструкції, оперованого суглоба, хірургічного методу, віку пацієнта та його маси тіла, загального стану здоров'я кожній людині після операції необхідна адекватна реабілітація, тому метою нашої роботи був аналіз основних реабілітаційних підходів, які застосовують для пацієнтів після ЕКС.

Основна частина. Найбільш вивченими з технологій ФРМ, які мають доведений ефект, є фізичні вправи в поєднанні з нейром'язовою електростимуляцією, кінезитерапія, кріотерапія, а також пресотерапія, яка

(с) М. О. Яводчак, Т. Г. Бакалюк, Г. О. Стельмах, 2020 ефективна для профілактики тромбоемболії після операційного втручання [10].

Переконливі докази ефективності окремих втручань на додаток до звичайних програм зі застосуванням кінезитерапії існують для кожного з наступних варіантів: тренування на біговій доріжці з частковою підтримкою маси тіла, одностороннє тренування 3 опором чотириголового м'яза (прооперована сторона) і вправи на велотренажері. У пізній післяопераційній фазі (інтервал між операціями > 8 тижнів) програми вправ послідовно покращують як порушення, так і здатність функціонувати. Вправи з обтяженням 3 ексцентричним посиленням тазостегнових і відвідних м'язів можуть бути найважливішим компонентом протоколів пізньої фази [6-8].

У результаті контрольованих випробувань фізичних вправ після ЕКС виникають три основні пропозиції: ранні післяопераційні протоколи повинні включати додаткові втручання, ефективність яких була доведена. Пізні післяопераційні програми корисні та повинні включати вправи з обтяженням 3 ексцентричним зміцненням кульшового суглоба [8].

Програма групової реабілітації настільки ж ефективна, як й індивідуальна реабілітація для стаціонарних пацієнтів, які перенесли заміну колінного та тазостег- 
нового суглобів, здатних витримувати навантаження після операції. Потенційна перевага групової терапії полягає в тому, що вона вимагає менших ресурсів [6].

Дослідження [12] оцінювало вплив стаціонарної водної фізіотерапії на додаток до звичайної фізіотерапії в палаті на відновлення сили, функцій і швидкості ходи після операції ЕКС. Основними критеріями була оцінка сили м'язів, швидкості ходи і функціональні можливості на 14 день. Встановлено, що спеціальна стаціонарна програма водної фізіотерапії позитивно впливає на швидке відновлення сили м'язів стегна після ЕКС. Це дослідження показало, що водну фізіотерапію можна безпечно розглядати у ранній післяопераційний період.

Порівняно з відсутністю втручання, 6-тижнева програма водної фізіотерапії сприяла значному зменшенню болю, поліпшенню фізичних функцій, сили м'язів і якості життя пацієнтів після ЕКС [13].

Із апаратних методів фізіотерапії - нервово-м'язова електростимуляція (HMEC) $\epsilon$ ефективним методом зміцнення чотириголового м'яза, який може зменшити втрату м'язів у період післяопераційного відновлення. Встановлено, що використання домашньої системи терапії НMEC, доданої до стандартного лікування, показало статистично значуще поліпшення сили чотириголового м'яза після ЕКС, що сприяло більш швидкому відновленню функції [11].

У дослідженні [7] показано, що НMEC при застосуванні до чотириголового м'яза хірургічної кінцівки протягом перших 6 тижнів після операції покращує швидкість відновлення після ЕКС і приводить до довгострокового збільшення сили і функціональних характеристик.

Реабілітаційні програми, що включають більш інтенсивні вправи з опором, які націлені на всі основні групи м'язів нижніх кінцівок, продемонстрували довгостроковий приріст сили м'язів і функціональних можливостей порівняно з програмами більш низької інтенсивності. Незважаючи на те, що найбільша сила і функціональна втрата відбуваються відразу після операції, з'являються нові докази того, що силові та функціональні прирости можуть бути досягнуті після періоду гострого післяопераційного відновлення за допомогою програм, орієнтованих на використання прогресивних водних вправ або ексцентричних вправ [10-12]. Тобто функціональне відновлення після ЕКС може бути покращено за рахунок використання НMEC і комплексної програми силових тренувань високої інтенсивності в поєднанні з традиційними підходами до реабілітації.
Результати дослідження [9] підтверджують потенційну користь кріотерапії для зменшення набряку та задоволеність під час післяопераційного одужання пацієнтів, які перенесли ЕКС, навіть при наявності навколосуглобових ін'єкцій для запобігання післяопераційного болю і кровотечі. Післяопераційна кріотерапія $\epsilon$ потенційно простим, неінвазивним та відносно недорогим варіантом для лікування після ТГА.

Також доказові дані має застосування в реабілітації пресотерапії (лімфодренаж) [3]. Цей метод, оснований на ритмічній стимуляції м'язів у певній послідовності з метою викликати природний дренаж лімфи і зменшити вміст рідин і токсинів. Результати клініко-лабораторних досліджень показали, що залежно від застосованих режимів метод пресотерапії всебічно сприяє регресу набряку за рахунок примусового повернення тканинної води до венозних і лімфатичних судин, зниженню внутрішньосудинного тиску, ліквідації відносної клапанної недостатності, зняттю механічного перевантаження судинних стінок і відновленню їх регулярних скорочень. Застосування пресотерапії в осіб із ризиком тромбозу ввійшло до ряду зарубіжних і вітчизняних клінічних рекомендацій. Зокрема, в українських клінічних протоколах надання медичної допомоги з профілактики тромботичних ускладнень розглядають пресотерапію серед механічних методів профілактики тромбоемболії легеневої артерії і тромбозу глибоких вен поряд із компресійними панчохами і венозною помпою (МОз України, 2007) [4, 5]. Таким чином, пресотерапія стає ніби проміжним методом між еластичним бинтуванням і ручним лімфодренажним масажем, що, ймовірно, і дозволяє йому в деяких випадках успішно заміщувати ці методи.

В. А. Жирнов зі співавт. [2], виходячи з власних даних, рекомендує включення методики стабілометрії в комплекс реабілітаційних заходів на ранніх термінах після ЕКС. У дослідженні [1] проаналізовано балансувальні параметри і показники опорної симетрії у пацієнтів після тотального ЕКС з урахуванням сторони ураження. Аналіз результатів дослідження до курсу реабілітації показав зміщення центру маси тіла у більшості пацієнтів. До кінця реабілітації частка осіб зі стабільним балансом зросла з 30,2 до 39,5 \% випадків, відзначалося зменшення зорового контролю положення тіла за рахунок підвищення пропріоцептивного контролю, а також зменшення впливу зору на функцію рівноваги ( $p<0,002)$. Отримані дані довели необхідність застосування стабілометрії в комплексній корекції наявних порушень на другому етапі реабілітації у пацієнтів після ЕКС. 
Тобто для підвищення ефективності проведеної реабілітації після ЕКС необхідно враховувати функціональну асиметрію ніг, коригувати програми реабілітації, спрямовувати їх на індивідуальний підбір комплексу фізичних вправ, фізіотерапевтичних методів, механотерапії, стабілотренінгу, для вдосконалення навички стояння, ходьби і відновлення нормальної життєдіяльності.

Висновки. 1. Для того, щоб протез не завдавав дискомфорту пацієнту і результати операції були хорошими, потрібна не тільки досконала робота хірурга,

\section{СПИСОК ЛІТЕРАТУРИ}

1. Горянная Н. А. Динамика показателей стабилометрии на втором этапе реабилитации пациентов после эндопротезирования тазобедренного сустава / Н. А. Горянная, Н. И. Ишекова, А. Н. Ишеков // Журн. мед.-биол. исследований. - 2020. - Т. 8, № 3. - С. 277-284.

2. Жирнов В. А. Реабилитация больных после эндопротезирования тазобедренного сустава. В кн. : Руководство по эндопротезированию тазобедренного сустава / В. А. Жирнов, С. И. Мальцев, С. Б. Шевченко. - СПб., 2008. - С. 314-321.

3. Зайцев Д. В. Об'ємний пневмопресинг: теорія і практика (огляд літератури) / Д. В. Зайцев, Г. Ю. Пишнов // Український медичний часопис. - 2014. - № 4. С. 127-132.

4. Таршинова Л. А. Метод объемного пневмопрессинга в лечении лимфедемы конечностей / Л. А. Таршинова, Т. В. Ельчиц, Д. В. Зайцев // Гематологія і трансфузіологія. 2015. - № 3. - С. 142-147.

5. Фіщенко В. О. Венозні тромбоемболічні ускладнення при ендопротезуванні суглобів нижніх кінцівок (огляд літератури) / В. О. Фіщенко, А. М. Рубленко // Травма. 2012. - № 13. - C. 1-7.

6. Group rehabilitation versus individual rehabilitation following knee and hip replacement: a pilot study with randomized, single-blind, cross-over design / I. Aprile, R. S. Rizzo, E. Romanini [et al.] // Eur. J. Phys. Rehabil. Med. - 2011. - Vol. 47 (4). - P. 551-559. Epub 2011 Jun 13. PMID: 21666574.

7. Bade M. J. Restoration of physical function in patients following total knee arthroplasty: an update on rehabilitation practices / M. J. Bade, J. E. Stevens-Lapsley // Curr. Opin. Rheumatol. - 2012. - Vol. 24 (2). - P. 208-214. DOI: 10.1097/ BOR.0b013e32834ff26d. PMID: 22249349. але і правильно організований курс реабілітації. Адже саме якісна реабілітація після ендопротезування приводить до більш повного відновлення працездатності хворих; підвищення якості їхнього життя; запобігання стійкій втраті працездатності.

2. Використання технологій ФРМ у реабілітації пацієнтів після ЕКС має ґрунтуватися на результатах якісних рандомізованих контрольованих клінічних досліджень, які слугують основою для розробки клінічних рекомендацій. Процес аналізу даних досліджень повинен мати регулярний характер.

8. Rehabilitation after total hip arthroplasty: a systematic review of controlled trials on physical exercise programs / M. Di Monaco, F. Vallero, R. Tappero, A. Cavanna // Eur. J. Phys. Rehabil. Med. - 2009. - Vol. 45 (3). - P. 303-317. Epub 2009 Feb 23. PMID: 19238130.

9. Efficacy of continuous local cryotherapy following total hip arthroplasty / K. Iwakiri, A. Kobayashi, Y. Takeuchi [et al.] // SICOTJ. - 2019. - Vol. 5 . - P. 13. DOI: 10.1051/sicotj/2019010. Epub 2019 May 3. PMID: 31050337; PMCID: PMC6498864.

10. Физическая терапия в реабилитации пациентов после эндопротезирования крупных суставов нижних конечностей : наукометрический анализ доказательных исследований / С. С. Хозяинова, Д. В. Ковлен, Г. Н. Пономаренко и др. // Вопросы курортологии, физиотерапии и лечебной физической культуры. - 2019. - № 96 (6). С. 22-31.

11. Neuromuscular electrical Stimulation use after total knee Arthroplasty Improves Early Return to Function: A Randomized Trial / A. K. Klika, G. Yakubek, N. Piuzzi [et al.] // J. Knee Surg. - 2020. DOI: 10.1055/s-0040-1713420. Epub ahead of print. PMID: 32610358.

12. Rahmann A. E. A specific inpatient aquatic physiotherapy program improves strength after total hip or knee replacement surgery: a randomized controlled trial / A. E. Rahmann, S. G. Brauer, J. C. Nitz // Arch. Phys. Med. Rehabil. - 2009. - Vol. 90 (5). - P. 745-755. DOI: 10.1016/j. apmr.2008.12.011. PMID: 19406293.

13. Rana Hinman S. Aquatic physical therapy for hip and knee osteoarthritis: Results of a single-blind randomized controlled trial / Rana S. Hinman, Sophie E. Heywood, Anthony R. Day // Physical Therapy. - Vol. 87, Issue 1. - P. 3243. - Access mode : https://doi.org/10.2522/ptj.20060006. 